\title{
SUPPLEMENTATION OF VITAMIN E AND C IN FEED ON MEAT QUALITY, THIOBARBITURIC ACID REACTIVE SUBSTANCE (TBARS) AND MYOGLOBIN LEVEL OF MUSCOVY DUCK MEAT
}

\author{
E. Tugiyanti ${ }^{1,2}$, T. Yuwanta ${ }^{1}$, Zuprizal $^{1}$ and Rusman $^{1}$ \\ ${ }^{1}$ Faculty of Animal Science, Gadjah Mada University, \\ Jl. Fauna 3 Bulaksumur, Yogyakarta 55281 - Indonesia \\ ${ }^{2}$ Permanent Address: Faculty of Animal Science, University of Jenderal Soedirman, \\ Jl. Dr. Soeparno, Purwokerto 53123 - Indonesia \\ Corresponding E-mail: tugiyanti.elly@gmail.com
}

Received January 02, 2014; Accepted February 28, 2014

\begin{abstract}
ABSTRAK
Penelitian ini bertujuan mengkaji suplementasi vitamin E dan C dalam pakan terhadap kualitas daging, kadar thiobarbituric acid reactive substances (TBARS) dan mioglobin daging itik Manila. Materi yang digunakan itik Manila jantan sebanyak 84 ekor dan perlakuan yang dicobakan ada 7 (tujuh) yang terdiri dari $\mathrm{E}_{0} \mathrm{C}_{0}$ : pakan tanpa disuplementasi vitamin $\mathrm{E}$ dan vitamin $\mathrm{C}, \mathrm{E}_{400}$ : pakan yang disuplementasi vitamin E sebesar $400 \mathrm{IU}, \mathrm{E}_{600}$ : pakan yang disuplementasi vitamin E sebesar $600 \mathrm{IU}$, $\mathrm{C}_{400}$ : pakan yang disuplementasi vitamin $\mathrm{C}$ sebesar $400 \mathrm{mg}, \mathrm{C}_{600}$ : pakan yang disuplementasi vitamin $\mathrm{C}$ sebesar $600 \mathrm{mg}, \mathrm{E}_{200} \mathrm{C}_{200}$ : pakan yang disuplementasi vitamin E sebesar $200 \mathrm{IU}$ dan vitamin $\mathrm{C}$ sebesar $200 \mathrm{mg}, \mathrm{E}_{300} \mathrm{C}_{300}$ : pakan yang disuplementasi vitamin $\mathrm{E}$ sebesar $300 \mathrm{IU}$ dan vitamin C sebesar $300 \mathrm{mg}$, masing-masing perlakuan diulang sebanyak 4 kali. Rancangan percobaan yang digunakan Rancangan Acak Lengkap (RAL) dan masing-masing perlakuan diulang sebanyak 4 kali. Data dianalisis menggunakan analisis variansi. Hasil analisis ragam menunjukkan bahwa perlakuan berpengaruh sangat nyata $(\mathrm{P}>0,01)$ terhadap kualitas fisik daging, kadar mioglobin dan angka TBARS. Simpulan penelitian ini adalah suplementasi vitamin $\mathrm{E}$ dan $\mathrm{C}$ mampu memperbaiki $\mathrm{pH}$ akhir daging itik Manila. Suplementasi vitamin E $300 \mathrm{IU}$ dan C $300 \mathrm{mg}$ pada pakan berprotein 21\% dan energi metabolis 3100 $\mathrm{kcal} / \mathrm{kg}$ mampu memperbaiki DIA, susut masak, flavor dan warna daging itik Manila, namun untuk menghasilkan keempukan yang tinggi sebaiknya pakan disuplementasi dengan vitamin E sebanyak 400 IU.
\end{abstract}

Kata kunci : mioglobin, senyawa volatil, kualitas daging

\begin{abstract}
This research was aimed to analyze vitamin $\mathrm{E}$ and $\mathrm{C}$ supplementation in feed on meet quality, thiobarbituric acid reactive substances (TBARS) and myoglobin level of muscovy duck. This research used 84 Indonesian muscovy duck divided into 7 group of experimental diet, namely $\mathrm{E}_{0} \mathrm{C}_{0}$ : basal feed without vitamin $\mathrm{E}$ and $\mathrm{C}$ supplementation, $\mathrm{E}_{400}$ : basal feed with $400 \mathrm{IU}$ of vitamin $\mathrm{E}$ supplementation, $\mathrm{E}_{600}$ : basal feed with $600 \mathrm{IU}$ of vitamin $\mathrm{E}$ supplementation, $\mathrm{C}_{400}$ : basal feed with $400 \mathrm{mg}$ vof itamin C supplementation, $\mathrm{C}_{600}$ : basal feed with $600 \mathrm{mg}$ of vitamin $\mathrm{C}$ supplementation, $\mathrm{E}_{200} \mathrm{C}_{200}$ : basal with $200 \mathrm{IU}$ of vitamin $\mathrm{E}$ and $200 \mathrm{mg}$ of vitamin $\mathrm{C}$ supplementation, $\mathrm{E}_{300} \mathrm{C}_{300}$ : basal feed with $300 \mathrm{IU}$ of vitamin $\mathrm{E}$ and $300 \mathrm{mg}$ of vitamin C. A completely randomized design was applied and each treatment had 4 replications. The data were analyzed using analysis of variance. Analysis of variance showed that treatments significantly affect $(\mathrm{P}>0.01)$ meat quality, myoglobin level and TBARS level. Vitamin $\mathrm{E}$ and $\mathrm{C}$ was proven able to improve final $\mathrm{pH}$ of muscovy duck meat. Supplementation of $300 \mathrm{IU}$ of vitamin $\mathrm{E}$ and $300 \mathrm{mg}$ of vitamin $\mathrm{C}$ at feed with $21 \%$ of protein and $3100 \mathrm{kcal} / \mathrm{kg}$ of energy could improve DIA, cooking loss, flavor, and color of muscovy duck meat; however, the highest meat tenderness was resulted from 400 IU vitamin E supplementation.
\end{abstract}

Keywords: myoglobin, volatile compounds, meat quality 


\section{INTRODUCTION}

Indonesian muscovy ducks, widely found in Java Island, are commonly under traditional breeding and unable to produce maximum performance and meat quality (CIVAS and FAO, 2006). Likewise, muscovy meat is less favorable in society due to its tough, dark, and musty meat.

Kim et al. (2008) found only $16 \%$ of white muscle fibers in duck breast meat but $100 \%$ of white muscle fibers in chicken breast meat. Besides, chicken breast has more protein than duck $(22.0 \%$ vs $20.1 \%)$ but less fat than duck (1.8\% vs $1.1 \%)$; accordingly, chicken $\mathrm{pH}$ is significantly lower than that of duck at 1-3 hour post mortem, but share common final $\mathrm{pH}$ at 24 hour. Qiao et al. (2001) reported that muscovy ducks, as well as other ducks, are mostly of red muscle fibers with minor white muscle fibers or $84 \%$ and $16 \%$, respectively, which affects meat composition, biochemical and sensory characteristics.

Color still affects psychological response, economical value and consumer preferability toward food product. Meat color is determined by level and status of myoglobin pigment (Mancini and Hunt, 2005) and the appearing color depends on the order, age, sex (Wawro et al., 2004), muscle type, feed, pre-slaughter treatment and stress, slaughtering method and storage condition (Haraf et al., 2009). At 8 weeks old, myoglobin in red meat fowl is $0.4 \mathrm{mg} / \mathrm{g}$, while in white meat fowl is $0.01 \mathrm{mg} / \mathrm{g}$ (Stadelman et al., 1988). Myoglobin content increases along with the age. Myoglobin and hemoglobin in meat can speed up fat oxidation that causes pungency and off-flavor because the increase of myoglobin is followed by $\mathrm{Fe}$. Ion $\mathrm{Fe}$ is catalyst to speed up oxidation rate and Fe level is affected by species, sex, age, muscle, myoglobin and hemoglobin activity and $\mathrm{Fe}$ (in ferrous), because $\mathrm{Fe}$ is easily oxidized and causes dark meat color (Meluzzi et al., 2009; Apriyantono and Lingganingrum, 2001, Tang et al., 2000; Barciela et al., 2008; Min et al., 2010; Yoon et al., 2010).

Fat oxidation can be prevented or impeded by antioxidant whose usage to living fowl has to meet some requirements, among which are nontoxic, non-flavoring, non-coloring, effective in small amount, inexpensive, and readily available. Well-known antioxidant is vitamin $\mathrm{C}$ and vitamin E. Vitamin $\mathrm{C}$ has 2 hydroxyl groups are easily oxidized, so it will easily release electrons and hydrogen to donate to the free radicals so that free radicals are not reactive or unstable (Sediaoetama, 1987) and as a regenerator of vitamin E (Rukmiarsih et al., 2011). Vitamin E protects fatty acid from oxidation by trapping free radicals and is effective in cell membrane, while vitamin $\mathrm{C}$ is very efficient in trapping some compounds such as superoxide, hydrogen peroxide, hydroxyl radicals and peroxyl radicals. There is synergic interaction between vitamin $\mathrm{E}$ and $\mathrm{C}$, in which the former is lipophilic and the latter is hydrophilic, also vitamin $\mathrm{C}$ can degenerate radical-formed vitamin E. (Lavoisier, 1998; Lamid, 1995; Winarsi, 2011). The objective this study was to determine the effect of vitamin $\mathrm{E}$ and $\mathrm{C}$ supplementation in feed on meet quality, thiobarbituric acid reactive substances (TBARS) and myoglobin level of muscovy duck.

\section{MATERIALS AND METHODS}

The materials used were 84 nine-week-old male muscovy duck weighing 850-1100 g, kept in 28 litter cage compartments each containing three heads. Muscovy ducks were reared for five weeks and at 14 weeks old, two ducks were taken from each compartment and slaughtered to take the meat and to analyze its physical quality, thiobarbituric acid reactive substances (TBARS) level and myoglobin level.

Ducks were given basal feed containing $21 \%$ protein, $3100 \mathrm{kcal} / \mathrm{kg}$ feed metabolic energy $(30 \%$ corn, $7 \%$ soy bean meal, $38.20 \%$ poultry meat meal, $6.10 \%$ oil, $0.10 \%$ L-lysin $\mathrm{HCl}, 0.30 \%$ DLmethionin, $0.20 \%$ topmix, $0.10 \% \mathrm{NaCl}$ and $1 \%$ $\mathrm{CaCO} 3)$, powdered vitamin $\mathrm{E}$ (d- $\alpha-$ tokoferolasetat) and vitamin C (L-ascorbic acid). Ducks were New Castle Disesase (NCD) vaccinated at first week. Drink water was supplied ad libitum and feed was given twice a day in the morning an afternoon.

Completely randomized design was applied, in which treatments were vitamin $\mathrm{E}$ and vitamin $\mathrm{C}$ supplementations to basal feed containing $21 \%$ protein and $3100 \mathrm{kcal} / \mathrm{kg}$ metabolic energy administered into seven groups, namely $\mathrm{E}_{0} \mathrm{C}_{0}$ : feed without Vit $E$ and Vit $C, E_{400}$ : feed plus 400 IU vitamin $\mathrm{E}, \mathrm{E}_{200}$ : feed plus $600 \mathrm{IU}$ vitamin $\mathrm{E}$, $\mathrm{C}_{400}$ : feed plus $400 \mathrm{mg} / \mathrm{kg}$ feed vitamin $\mathrm{C}, \mathrm{C}_{400}$ : feed plus $600 \mathrm{mg} / \mathrm{kg}$ feed vitamin $\mathrm{C}$ sebanyak, $\mathrm{E}_{200} \mathrm{C}_{200}$ : feed plus $200 \mathrm{IU}$ vitamin $\mathrm{E}$ and 200 $\mathrm{mg} / \mathrm{kg}$ feed vitamin $\mathrm{C}$, and $\mathrm{E}_{300} \mathrm{C}_{300}$ : feed plus 300 IU vitamin $\mathrm{E}$ and $300 \mathrm{mg} / \mathrm{kg}$ feed vitamin $\mathrm{C}$. Each treatment was subject to four replications. The obtained data were then analyzed using 
analysis of variance and any differences were further subject to honestly significant difference Test.

The observed parameters were meat quality ( $\mathrm{pH}$, water holding capacity, cooking loss and meat tenderness), level of TBARS and myoglobin. Measurement was conducted using pH meter for $\mathrm{pH}$ (Bouton et al., 1971), Hamm method for WHC (Soeparno, 2005) and Soeparno's (2005) method for cooking loss. TBARS level was estimated according to AOAC (1995). The $10 \mathrm{~g}$ meat sample added with $50 \mathrm{ml}$ aquadest was mashed for two minutes, moved into distillation flask while being rinsed with $47.5 \mathrm{ml}$ aquadest and added with $2.5 \mathrm{ml} \mathrm{HCL}$ to reach 1.5 $\mathrm{pH}$. Boiling stones were then folded into the mixture, attached to the distillator, distillated using high speed electric mantle heater for 10 minutes to obtain $50 \mathrm{ml}$ distillate. The distillate was stirred well, taken $5 \mathrm{ml}$ then placed in reaction tube with cap then added with $5 \mathrm{ml}$ TBA reagent. Tube was closed, well shaken and heated in boiling water for 35 minutes. Blank solution: $5 \mathrm{ml}$ aquadest $+5 \mathrm{ml}$ TBA reagent was cooled for 10 minutes. Absorbance (D) was read using spectrophotometer, Z528nm with blank solution as zero point.

$\mathrm{TBA}=7.2 \mathrm{D}$ ( $\mathrm{mg} / 100 \mathrm{~kg}$ sample)

Myoglobin level according to Lerner (2009). From each sample $2 \mathrm{ml}$ of the supernatant were saturated with $75 \%$ ammonium sulphate $(0.525$ g.ml-1) to precipitate the haemoglobin while keeping the mioglobin in the solution (1). Precipitated haemoglobin was separated by centrifugation at $2000 \mathrm{rpm}$ at $21^{\circ} \mathrm{C}$ for $45 \mathrm{~min}$. This solution was used for evaluation of mioglobin using the modified kinetic method with o-tolidine as described above. The results were processed statistically using software "Statgraphic Plus". The dependence of A630 on sample concentration was linear and the calculated relation was:

mg.l-1 = $-0.0804722+14.6076 \cdot \mathrm{A} 630$ (correlation coefficient; $r=0.992784$ )

Research was conducted in muscovy duck experimental farm in Animal Science Faculty, Jenderal Soedirman University, Nutrition Laboratory PAU Gadjah Mada University, Laboratory of Food and Nutrition of Agricultural Technology Faculty Gadjah Mada University and Chemistry Laboratory of Mathematics and Science Program, Jenderal Soedirman University.

\section{RESULTS AND DISCUSSION}

\section{Meat Quality}

The $\mathrm{pH}$ of muscovy duck meat in this research was 5-5.49 which was relatively similar to $5,7 \pm 0,05$ of male muscovy by Wawro et al. (2004). Table 1 shows that $\mathrm{E}_{0} \mathrm{C}_{0}$ was significantly different $(\mathrm{P}<0.01)$ from all other treatments; however, $\mathrm{E}_{400}, \mathrm{E}_{600}, \mathrm{C}_{400}, \mathrm{C}_{600}$, dan $\mathrm{E}_{300} \mathrm{C}_{300}$ were not different. This is because vitamin $\mathrm{C}$ and $\mathrm{E}$ function as antioxidant that prevents the forming of free radicals and increases oxidative stability of meat which affects muscle glycogen depletion rate. It was in line with Bou et al.(2006) that 150 $\mathrm{mg} / \mathrm{kg}$ of $\alpha$-tokoferol asetat supplementation in broiler ration for 32 days could increase chicken oxidative stability. El-habbak et al. (2011) reported that vitamin $\mathrm{E}$ and $\mathrm{C}$ have hydroxyl compound and are easy to donor electron and hydrogen to free radicals. Consequently, free radicals formation relatively more slowly and the cattle get healthier. In healthier cattle, muscle glycogen depletion rate is slower than that of stressed or sick animals. Accordingly, meat $\mathrm{pH}$ of muscovy $\mathrm{E}_{0} \mathrm{C}_{0}$ is lower than that of other treatments. It was in accordance with Choi et al. (2010) and Kim et al. (2009) that meat $\mathrm{pH}$ depletion rate was affected by antioxidant intake before slaughtering. Antioxidant effectively slow down the glycogen store depletion into lactic acid and prevent oxidative process by free radicals.

WHC of muscovy duck meat in this research ranged from $33.95 \pm 0.09$ to $36.52 \pm 0.30$. This values were higher than that of Utami et al. (2011) namely $26.75-33.77 \%$ and $26.13 \%$, respectively. Table 1 shows that feed without vitamin $\mathrm{E}$ and $\mathrm{C}$ supplementation $\left(\mathrm{E}_{0} \mathrm{C}_{0}\right)$ produced different WHC ( $\mathrm{P}>0.01)$ from all other treatments; $\mathrm{E}_{400}$ was not different $(\mathrm{P}>0.05)$ from $\mathrm{C}_{400}, \mathrm{C}_{600}$ and $\mathrm{E}_{200} \mathrm{C}_{200}$. Also $\mathrm{E}_{200} \mathrm{C}_{200}$ was not different from $\mathrm{E}_{300} \mathrm{C}_{300}$. It demonstrated that muscovy WHC was affected by level of vitamin $\mathrm{E}$ and $\mathrm{C}$ administered. Vitamin E effectively maintains cell membrane integrity and meat juice loss that eventually affects WHC (Petraci and Cavani,2012), protects cell from endogenous free radicals (Rahman, 2003) and affects body fat (Rusmana et al., 2008). Vitamin $\mathrm{C}$ functions in carnitine synthesis that essentially serves in fatty acid transport from cytosol to mitochondria in fat biosynthesis, therefore WHC in vitamin C treatment is lower than that of vitamin E. The lower intramuscular fat level, the lower is water holding capacity by meat protein. 
Table 1. Meat Quality of 14 Weeks old Muscovy Duck Given Vitamin C and E Supplementation

\begin{tabular}{lccccccc}
\hline Parameters & $\mathrm{E}_{0} \mathrm{C}_{0}$ & $\mathrm{E}_{400}$ & $\mathrm{E}_{600}$ & $\mathrm{C}_{400}$ & $\mathrm{C}_{600}$ & $\mathrm{E}_{200} \mathrm{C}_{200}$ & $\mathrm{E}_{300} \mathrm{C}_{300}$ \\
\hline $\mathrm{pH}$ & $5.00 \pm 0.00^{\mathrm{a}}$ & $5.49 \pm 0.15^{\mathrm{b}}$ & $5.41 \pm 0.06^{\mathrm{b}}$ & $5.38 \pm 0.09^{\mathrm{b}}$ & $5.29 \pm 0.17^{\mathrm{b}}$ & $5.39 \pm 0.10^{\mathrm{b}}$ & $5.42 \pm 0.01^{\mathrm{b}}$ \\
WHC (\%) & $33.95 \pm 0.09^{\mathrm{a}}$ & $35.04 \pm 0.11^{\mathrm{b}}$ & $35.64 \pm 0.17^{\mathrm{b}}$ & $34.93 \pm 0.41^{\mathrm{b}}$ & $34.83 \pm 0.19^{\mathrm{b}}$ & $36.11 \pm 0.11^{\mathrm{bc}}$ & $36.52 \pm 0.30^{\mathrm{c}}$ \\
$\begin{array}{l}\text { Cooking } \\
\text { loss (\%) }\end{array}$ & $36.60 \pm 0.65^{\mathrm{d}}$ & $36.13 \pm 0.48^{\mathrm{d}}$ & $33.47 \pm 1.14^{\mathrm{c}}$ & $32.43 \pm 0.80^{\mathrm{bc}}$ & $33.04 \pm 0.66^{\mathrm{bc}}$ & $31.55 \pm 0.57^{\mathrm{b}}$ & $27.48 \pm 0.74^{\mathrm{a}}$ \\
$\begin{array}{l}\text { Tenderness } \\
(\mathrm{kg} / \mathrm{cm} 2)\end{array}$ & $5.80 \pm 0.37^{\mathrm{b}}$ & $4.76 \pm 0.39^{\mathrm{a}}$ & $5.38 \pm 0.27^{\mathrm{ab}}$ & $5.80 \pm 0.37^{\mathrm{b}}$ & $6.85 \pm 0.53^{\mathrm{c}}$ & $6.13 \pm 0.44^{\mathrm{bc}}$ & $5.94 \pm 0.40^{\mathrm{b}}$ \\
\hline
\end{tabular}

$\mathrm{E}_{0} \mathrm{C}_{0}$ : feed without Vit $\mathrm{E}$ and Vit $\mathrm{C}$ supplementation; $\mathrm{E}_{400}$ :feed plus $400 \mathrm{IU}$ of vitamin $\mathrm{E} ; \mathrm{E}_{600}$ : feed plus 600 IU of vitamin $\mathrm{E}, \mathrm{C}_{400}$ : feed plus $400 \mathrm{mg} / \mathrm{kg}$ feed of vitaminC; $\mathrm{C}_{600}$ : feed plus $600 \mathrm{mg} / \mathrm{kg}$ feed of vitamin $\mathrm{C}$, $\mathrm{E}_{200} \mathrm{C}_{200}$ : feed plus $200 \mathrm{IU}$ vitamin $\mathrm{E}$ and $200 \mathrm{mg} / \mathrm{kg}$ feed of vitamin $\mathrm{C}$ and $\mathrm{E}_{300} \mathrm{C}_{300}$ : feed plus $300 \mathrm{IU}$ of vitamin $\mathrm{E}$ and $300 \mathrm{mg} / \mathrm{kg}$ feed of vitamin $\mathrm{C}$. abcd shows higly significant $(\mathrm{P}<0.01)$

Cooking loss of muscovy meat in this research ranged from $27.48 \pm 0.74$ to $36.60 \pm$ $0.65 \%$. These values were lower than that of Utami et al. (2011) but higher than that of Omojola (2007) on male muscovy namely $40.18 \%$ and $25.50 \%$, respectively. $\mathrm{E}_{0} \mathrm{C}_{0}$ was not different $(\mathrm{P}>0,05)$ from $\mathrm{E}_{400}$, and $\mathrm{E}_{600}$ was not different from $\mathrm{C}_{400}$ and $\mathrm{C}_{600}$. Furthermore, $\mathrm{E}_{200} \mathrm{C}_{200}$ was not different from $\mathrm{C}_{400}$ and $\mathrm{C}_{600}$, but $\mathrm{E}_{200} \mathrm{C}_{200}$ was different from $\mathrm{E}_{300} \mathrm{C}_{300}$ (Table 1). Cooking loss process deals with water holding capacity as informed by Soeparno (2005) that the higher water holding capacity, the less juice loss during cooking, besides cooking loss is also affected by meat intramuscular fat. Muscle with high intramuscular fat tends to have high WHC and low cooking loss, because intramuscular fat resists or lessen meat juice extracted during cooking. Prawirokusumo (1990) stated that vitamin $\mathrm{E}$ is fat-soluble, effectively prevents fat oxidation that damages tissues; therefore, cooking lost when boiling meat can be reduced. Linder (1992) supported that at molecular level, vitamin $\mathrm{C}$ becomes reductive like vitamin $\mathrm{E}$ and active form. This characteristics is assumed to be able to defend cell stability from damage so that meat juice loss can be resisted.

Meat tenderness of 14 weeks old male muscovy that supplemented with vitamin $\mathrm{C}$ and $\mathrm{E}$ in feed have significantly effect $(\mathrm{P}<0.01) . \mathrm{E}_{0} \mathrm{C}_{0}$ was different from $(\mathrm{P}<0,01)$ all treatments. $\mathrm{E}_{400}$ was not different from $(\mathrm{P}>0.05) \mathrm{E}_{600}$, but $\mathrm{E}_{600}$ was not different from $(\mathrm{P}>0.05) \mathrm{C}_{400}, \mathrm{E}_{200} \mathrm{C}_{200}$ and $\mathrm{E}_{300} \mathrm{C}_{300}$. Vitamin $\mathrm{E}$ is fat-soluble that maintains plasma membrane integrity (Khan et al., 2011) and eventually lowers meat juice loss so that drip depletes and WHC increases. This was in accordance with $\mathrm{Li}$ et al. (2009) that vitamin $\mathrm{E}$ supplementation in feed decrease the drip loss and increase tenderness but not significantly affected carcass production, while vitamin $\mathrm{C}$ is watersoluble antioxidant that significantly serves in forming intercellular collagen and fat metabolism. Collagen is a type of protein as the main component in connective tissue (Soeparno, 2005), so vitamin $\mathrm{C}$ efficacy in tenderness is still unstable. On the other hand, vitamin $\mathrm{C}$ synergized vitamin $\mathrm{E}$ will effectively increase meat tenderness.

\section{TBARS and Myoglobin Level}

The effect of vitamin $\mathrm{E}$ and $\mathrm{C}$ supplementations in feed resulted in $0.43-0.86$ $\mathrm{mg} / 100 \mathrm{~g}$ of TBARS level, or higher than that of muscovy fed with Pluchea indica scoring 0.302 $0.359 \mathrm{mg} / 100 \mathrm{~g}$ (Rukmiasih et al.,2009). Table 2 showed that feed supplemented with vitamin $\mathrm{C}$ and $\mathrm{E}$ significantly affected $(\mathrm{P}<0.01)$ myoglobin of 14 weeks old male muscovy. $\mathrm{E}_{200} \mathrm{C}_{200}$ was not different $(\mathrm{P}>0.05)$ from $\mathrm{E}_{300} \mathrm{C}_{300}$, also between $\mathrm{E}_{0} \mathrm{C}_{0}$ and $\mathrm{E}_{400}$ and between $\mathrm{E}_{400}$ and $\mathrm{C}_{400}, \mathrm{C}_{600}$. Oxidation process gets faster when in alkali surrounding. Free oxygen in the air will oxidized double chained unsaturated fatty acid in food, and fatty acid oxidation would be followed by $\mathrm{H}_{2} \mathrm{O}_{2}$ formation that induced pungency. However, if antioxidant exists in feed, the active peroxide formed would react with antioxidant to prevent 
free radicals formation and eventually slow down the formation of malonaldehyd (Lukman et al., 2007). Table 2 shows that antioxidant intake either vitamin $\mathrm{C}$ or $\mathrm{E}$ could impede oxidation and malonaldehyd formation in muscovy meat, those were observed from lower TBARS value compared to muscovy fed without vitamin $\mathrm{C}$ and E supplementation. Oxidative rate would differ due to the effect of characteristics and efficacy of antioxidant intake, meat fatty acid and unsaturated fatty acid. Fat level and unsaturated fatty acid of muscovy skinned meat in each treatment was relatively high, in that $\mathrm{E}_{0} \mathrm{C}_{0}$ was $6.72 \%$ and $42.64 \%, \mathrm{E}_{400}$ was $556 \%$ and $49.55 \%, \mathrm{E}_{600}$ was $7.23 \%$ and $37.64 \%, \mathrm{C}_{400}$ was $7.12 \%$ and $46.85 \%$, $\mathrm{C}_{600}$ was $6.89 \%$ and $43.41 \%, \mathrm{E}_{200} \mathrm{C}_{200}$ was $7.07 \%$ and $32.86 \%, \mathrm{E}_{300} \mathrm{C}_{300}$ was $7.11 \%$ and $45.01 \%$. Furthermore, peroxide and TBARs scores according to Gheisari (2011) was positively correlated. Critical control point of meat tested by TBARS was 15 mg/kg sampel (Sanger,2010).
Myoglobin is monomeric protein serves as oxygen storage site on skeletal muscle cell (striated muscle). This protein is composed of at least 154 amino acid chains and one heme compound (porphyrin chain with one Fe atom). Myoglobin level of breast meat of muscovy ranged from $4.98 \pm 1.61$ to $9.07 \pm 0.57 \mathrm{mg} / \mathrm{g}$. Myoglobin level in this research was higher than that of Gheisari (2011) stated that chicken myoglobin was $0.31 \pm 0.07 \mathrm{mg} / \mathrm{g}$. Feed supplemented with vitamin $\mathrm{C}$ and $\mathrm{E}$ significantly affected $(\mathrm{P}<0.01)$ myoglobin of 14 weeks old male muscovy. $\mathrm{E}_{300} \mathrm{C}_{300}$ was not different from $\mathrm{E}_{0} \mathrm{C}_{0}, \mathrm{E}_{400}, \mathrm{E}_{600}, \mathrm{C}_{400}, \mathrm{C}_{400}$ and $\mathrm{E}_{200} \mathrm{C}_{200} \cdot \mathrm{C}_{400}$ and $\mathrm{C}_{600}$ was different from $\mathrm{E}_{0} \mathrm{C}_{0}, \quad \mathrm{E}_{400}$ and $\mathrm{E}_{600}$. $\mathrm{E}_{200} \mathrm{C}_{200}$ was different from $\mathrm{E}_{0} \mathrm{C}_{0}$ (Table 2 and Figure 1). The lowest muscovy myoglobin level was due to feed supplemented with vitamin $\mathrm{C}$, because vitamin $\mathrm{C}$ can increase triglyceride and affect muscle glycogen stores. Glycolysis rate became slower causing denaturation of muscle

Table 2. Myoglobin and TBARS Level of 14 Week old Muscovy Duck Meat Given Vitamin C and E Supplementation

\begin{tabular}{lccccccc}
\hline \multicolumn{1}{c}{ Parameters } & $\mathrm{E}_{0} \mathrm{C}_{0}$ & $\mathrm{E}_{400}$ & $\mathrm{E}_{600}$ & $\mathrm{C}_{400}$ & $\mathrm{C}_{600}$ & $\mathrm{E}_{200} \mathrm{C}_{200}$ & $\mathrm{E}_{300} \mathrm{C}_{300}$ \\
\hline $\begin{array}{l}\text { TBARS } \\
\text { (mg MA/100 g) }\end{array}$ & $0.86 \pm 0.14^{\mathrm{c}}$ & $0.82 \pm 0.01^{\mathrm{c}}$ & $0.52 \pm 0.00^{\mathrm{ab}}$ & $0.52 \pm 0.01^{\mathrm{ab}}$ & $0.62 \pm 0.01^{\mathrm{b}}$ & $0.44 \pm 0.01^{\mathrm{a}}$ & $0.43 \pm 0.01^{\mathrm{a}}$ \\
$\begin{array}{l}\text { Myoglobin } \\
\text { level (mg/g) }\end{array}$ & $9.07 \pm 0.57^{\mathrm{b}}$ & $8.62 \pm 0.98^{\mathrm{b}}$ & $8.09 \pm 1.34^{\mathrm{b}}$ & $5.16 \pm 2.17^{\mathrm{a}}$ & $4.98 \pm 1.61^{\mathrm{a}}$ & $5.74 \pm 1.34^{\mathrm{a}}$ & $7.41 \pm 0.13^{\mathrm{ab}}$ \\
\hline
\end{tabular}

$\mathrm{E}_{0} \mathrm{C}_{0}$ : feed without Vit $\mathrm{E}$ and Vit $\mathrm{C}$ supplementation; $\mathrm{E}_{400}$ : feed plus $400 \mathrm{IU}$ of vitamin $\mathrm{E} ; \mathrm{E}_{600}$ : feed plus 600 IU of vitamin $\mathrm{E}, \mathrm{C}_{400}$ : feed plus $400 \mathrm{mg} / \mathrm{kg}$ feed of vitaminC; $\mathrm{C}_{600}$ : feed plus $600 \mathrm{mg} / \mathrm{kg}$ feed of vitamin $\mathrm{C}$, $\mathrm{E}_{200} \mathrm{C}_{200}$ : feed plus $200 \mathrm{IU}$ vitamin $\mathrm{E}$ and $200 \mathrm{mg} / \mathrm{kg}$ feed of vitamin $\mathrm{C}$ and $\mathrm{E}_{300} \mathrm{C}_{300}$ : feed plus $300 \mathrm{IU}$ of vitamin $\mathrm{E}$ and $300 \mathrm{mg} / \mathrm{kg}$ feed of vitamin $\mathrm{C}$. ${ }^{\text {abcd }}$ shows higly significant $(\mathrm{P}<0.01)$

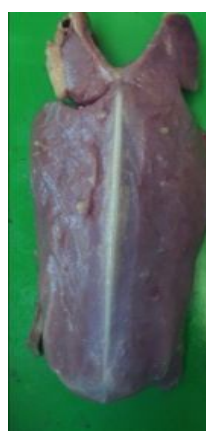

$\mathrm{E}_{0} \mathrm{C}_{0}$

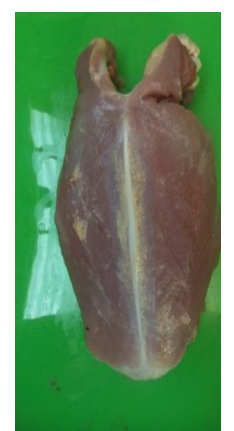

$\mathrm{E}_{400}$

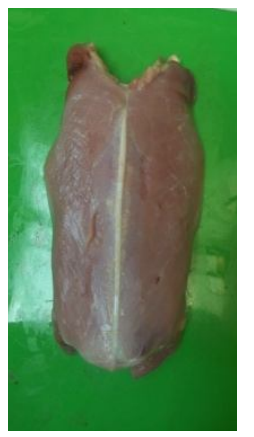

$\mathrm{E}_{600}$

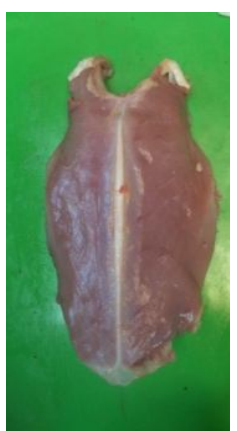

$\mathrm{C}_{400}$

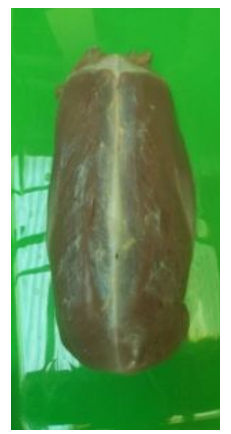

$\mathrm{C}_{600}$

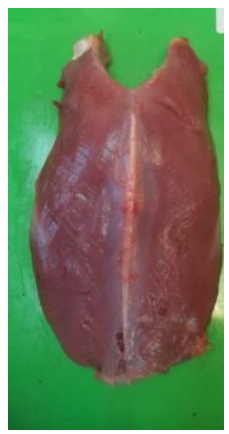

$\mathrm{E}_{200} \mathrm{C}_{200}$

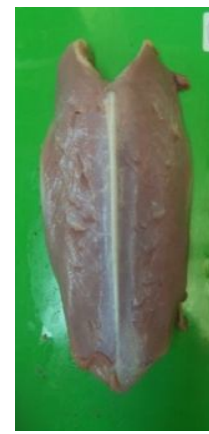

$\mathrm{E}_{300} \mathrm{C}_{300}$

Figures 1. Meat Color of Each Treatment 
protein including myoglobin. Nelson and Cox (2008) stated that myoglobin has high oxygen holding capacity, making it easily oxidized, and turning into bright red $(\mathrm{Mb})$ oxidation. Fletcher (2003) and Allen (2009) stated that myoglobin consists of heme and globin compound. Heme compound is hydrophobic consisting of one $\mathrm{Fe}$ ion with four nitrogen porphyrin rings. The sixth $\mathrm{Fe}$ bond is easily oxidized that turns meat color into dark. Zouari et al. (2010) mentioned that vitamin $\mathrm{E}$ prevents lipid oxidation, is effective to stabilize meat color, but excessive amount will lose the red color in meat because vitamin $\mathrm{E}$ can induce metmyoglobin very fast. Besides myoglobin, meat color is also affected by the extracted hemoglobin when slaughtered. Hemoglobin level of each treatment at slaughtering showed that $\mathrm{E}_{0} \mathrm{C}_{0}$ was $11.28 \pm 2.88$ $\mathrm{g} / \mathrm{dl} ; \mathrm{E}_{400}$ was $14.75 \pm 3.76 \mathrm{~g} / \mathrm{dl} ; \mathrm{E}_{600}$ was $12.55 \pm$ $3.76 \mathrm{~g} / \mathrm{dl} ; \mathrm{C}_{400}$ was $16.35 \pm 2.06 \mathrm{~g} / \mathrm{dl} ; \mathrm{C}_{600}$ was $11.70 \pm 1.57 \mathrm{~g} / \mathrm{dl} ; \mathrm{E}_{200} \mathrm{C}_{200}$ was $13.40 \pm 2.51 \mathrm{~g} / \mathrm{dl}$ and $\mathrm{E}_{300} \mathrm{C}_{300}$ was $13.18 \pm 2.01 \mathrm{~g} / \mathrm{dl}$.

\section{CONCLUSION}

Supplementation of $300 \mathrm{IU}$ vitamin $\mathrm{E}$ and $300 \mathrm{mg}$ vitamin $\mathrm{C}$ into feed with $21 \%$ protein and $3100 \mathrm{kcal} / \mathrm{mg}$ metabolic energy can recover WHC, cooking loss, flavor and meat color of muscovy duck, however, the highest meat tenderness was resulted from 400 IU vitamin E supplementation.

\section{ACKNOWLEDGMENTS}

The author would like to thank to Directorate General of Higher Education, Ministry of Education and Culture for the Doctorate scholarship in Post Graduate Animal Science Study Program, Gadjah Mada University Yogyakarta. Gratitude also goes to the Dean of Animal Science Faculty, Jenderal Soedirman Univerity for granting study permit.

\section{REFERENCES}

AOAC.1995. Official Method of Analysis of The Association of Official Analitic Chemist. Arlington Virginia Inc. USA.

Allen, K. 2009. A novel role for non heme iron in myoglobin oxidation: an examination of the antioxidant effects of iron chelating compounds in meat and myoglobin model systems. Dissertations. Utah State
University.

Apriyantono, A. and F.S. Lingganingrum. 2001. Off-flavor pada daging unggas.. Proceedings: Pengembangan agribisnis unggas air sebagai peluang usaha baru. Prosiding Lokakarya Unggas Air 6-7 August 2001. P. $58-72$

Barciela, J., C. Herrero, S. García-Martín and R.M. Peña. 2008. A brief study of the role of selenium as antioxidant. Elec. J. Env. Agric. Food Chem. 7: 3151-3155

Bou, R., S. Grimpa, F. Guardiola, A.C. Barroeta and R. Codony. 2006. Effects of various fatsources, alpha tocopheryl acetate, and ascorbic acid supplements on fatty acid composition and alpha-tocopherol content in raw and vacuum-packed, cooked dark chicken meat. J. Poult. Sci. 85(8):14721481.

Bouton, P. E., P. V. Harris, and W. R. Shorthose. 1971. Effect of ultimate $\mathrm{pH}$ upon the water holding capacity and tenderness of mutton. J. Food Sci. 36:435-439.

CIVAS and FAO. 2006. A Review of Free Range Duck Farming System In Indonesia and Assessment of Their Implication In The Spreading of The Highly Pathogenic (H5n1) Strain of Avian Influenza (HPAI). Final Report from Center for Indonesian Veterinary Analitycal Studies (CIVAS) and Food and Agriculture Organization (FAO) of the United Nations. Jakarta. Indonesia

Choi,I.H., W.Y. Park and Y.J. Kim. 2010. Effects of dietary garlic powder and atocopherol supplementation on performance, serum cholesterol levels and meat quality of chicken. J. Poult. Sci. 89:1724-1731

El-Habbak, M.M., A.A. El-Ghamry, G.M.ElMallah, H.H. Younis and E.M. El-Komy. 2011. Influence of dietary vitamin e and c supplementation on performance and some metabolis response of broiler chicks subjected to heat stress. World J. Agric. Sci. 7(3): 258-269

Fletcher, D.L. 2003. Poultry meat colour. In: Poultry Meat Science ,Poultry Science Symposium Series Vol 25. Edited by R.I. Richardson and G.C. Mead. CABI Publishing.

Gheisari, H. R. 2011. Correlation between acid, TBA, peroxide and iodine values, catalase and glutathione peroxidase activities of chicken, cattle and camel meat during refrigerated storage. Vet. World. 4(4):153- 


\section{7}

Haraf, G., J. Ksiazkiewicz, J. Woloszyn and A.

Okruszek. 2009. Characteristic of meat colour of different duck populations. Archiv Tierzucht. 52:527-537

Khan, R.U., S. Naz, Z. Nikousefat, V. Tufarelli, M. Javdani,N. Rana and V. Laudadio. 2011. Effect of vitamin $\mathrm{E}$ in heat-stressed poultry. World's Poult. Sci.J. 67: 469-478

Kim, G.D., J.Y. Jeong, S.H. Moon, Y.H. Hwang, G.B. Park and S.T. Joo. 2008. Effects of muscle fibre type on meat characteristics of chicken and duck breast muscle. Division of Applied Life Science, Graduate School, Gyeongsang National University, Jinju, Gyeongnam 660-701, Korea.

Kim, Y.J., S.K. Jin and H.S. Yang. 2009. Effect of dietary blub and husk on the physicochemical properties of chicken meat. J. Poult. Sci. 88: 398-405

Lamid, A. 1995. Vitamin E Sebagai Antioksidan. Artikel. Media Litbangkes 5 (1): 14-16

Lavoisier, A.L. 2008. Chemical and Physiological Properties of Vitamins. In: The Vitamins, Fundamental Aspects In Nutrition And Health. Third Edition, Gerald F. Combs (editor), Academic Press. London. P. 35-74

Lerner, P.T. 2009. Evaluation of haemaglobin and myoglobin in poultry slaughtered by stunning and kosher slaughter. Folia Veterinaria. 53(1):25-27

Li ,W.J, G.P. Zhao, J.L. Chen, M.Q. Zheng and J. Wen. 2009. Influence of dietary vitamin E supplementation on meat quality traits and gene expression related to lipid metabolism in the beijing-you chicken. British Poult. Sci. 50(2): 188-198

Linder, M. C. 1992. Nutritional Biochemistry and Metabolism. California State University.

Lukman, D.W., A.W. Sanjaya, M. Sudarwanto, R.R. Soejoedono, T. Purnawarman and H. Latif. 2007. Higiene Pangan. Fakultas Kedokteran Hewan, Institut Pertanian Bogor. Bogor.

Mancini, R.A. and M.C. Hunt. 2005. Current research in meat color. Meat Sci. 57: 100-21.

Meluzzi, A., F. Sirri, M.Petracci, M. Bianci and M. Isidori. 2009. Survey carcass pigmentation variability of yellow skinned broiler chickens. The 2nd. Mediterranean Summit of WPSA. Antalya, Turkey, 4-7 October 2009. P. 393-397

Min B, J.C. Cordray and D.U Ahn. 2010. Effect of $\mathrm{NaCl}$, myoglobin, $\mathrm{Fe}(\mathrm{II})$, and $\mathrm{Fe}(\mathrm{III})$ on lipid oxidation of raw and cooked chicken breast and beef loin. J. Agric. Food Chem. 58: 600-605.

Nelson, D.L. and M.M. Cox. 2008. Lehninger: Principles of biochemistry. Fifth Edition. W.H. Freeman And Company. USA.

Omojola, A.B. 2007. Carcass and organoleptic characteristics of duck meat as influenced by breed and sex. Int. J. Poult. Sci. 6(5):329334

Prawirokusumo, S. 1990. Biokimia Nutrisi (Vitamin). Edisi 1. Badan Penerbit Fakultas Ekonomika dan Bisnis (BPFE), UGM. Yogyakarta.

Petracci,M. and C. Cavani. 2012. Muscle growth and poultry meat quality issues. Nutrients 4 : 1-12

Qiao.M, D.L. Fletcher, D.P. Smith and J.K. Northcutt. 2001. The Effect of broiler breast meat color on ph, moisture, water holding capacity and emulsification capacity. J. Poult. Sci. 80:676- 680

Rahman, I. 2003. Oxidative stress, chromatin remodelling and gene transciption in inflammation and chronic lung disease. J.Biochem. Mol. Biol. 36:95-109.

Ridwan, E. 2012. Kajian interaksi zat besi dengan zat gizi mikro lain dalam suplementasi. Penel. Gizi Makan. 35(1):49-54

Rukmiasih, A. S. Tjakradidjaja, Sumiati, and H. Huminto. 2009. Dampak penggunaan beluntas dalam upaya menurunkan kadar lemak daging terhadap produksi dan kadar lemak telur itik lokal. J. Ilmu Pertanian Indonesia. 14(1):73-82

Rukmiarsih, PS. Hardjosworo,P.P. Ketaren and P.R. Matitaputty. 2011. Penggunaan beluntas, vitamin $\mathrm{C}$ dan $\mathrm{E}$ sebagai antioksidan untuk menurunkan off-odor daging itik Alabio dan Ciheteup. J. Ilmu Ternak dan Veteriner. 16(1):9-16

Rusmana,D., D. Natawiharja and Happali. 2008. The Effect of giving ration containing sardinella oil and vitamin e on fat and cholesterol of meat in broiler chicken. J. Ilmu Ternak. 8(1):19-24

Sanger, G. 2010. Oksidasi lemak ikan tongkol (auxfs thazard) asap yang direndam dalam larutan ekstrak daun sirih. Pacific J. (5): 870 $-873$

Sediaoetama, A.D. 1987. Vitaminologi. Balai Pustaka. Jakarta.

Soeparno, 2005. Ilmu dan Teknologi Daging. Cetakan ketiga. Gadjah Mada Uni-versity 
Press. Yogyakarta.

Stadelman W.J, V.N Olson, GA Shemwell, S. Pasch. 1988. Egg and Poultry Meat Processing. Ellis Horwood Ltd. VCH, Chichester, England.

Tang L, Y. Zhang, Z. Qian and X. Shen. 2000. The mechanism of $\mathrm{Fe} 2+-$-initiated lipid peroxidation in liposomes : the dual function of ferrous ions, the roles of the pre-existing lipid peroxides and the lipid peroxyl radical. Biochem. J. 352:27-36

Wawro K., W. Wawro E, K. Kleczek and W. Brzozowski. 2004. Slaughter value and meat quality of muscovy ducks, pekin ducks and their crossbreeds and evaluation of heterosis effect. Arch Tierz 47:287 - 99

Winarsi, H. 2011. Antioksidan Alami dan Radikal Bebas. Potensi dan Aplikasinya dalam Kesehatan. Cetakan ke-5. Penerbit Kanisius. Yogyakarta.

Yoon J.H, M.S Lee, J.H. Kang. 2010. Reaction of ferritin with hydrogen peroxide induces lipid peroxidation. BMB reports : 219-224.

Zouari N., F. Elgharbi, N. Fakhfakh, A. B. Bacha, Y. Gargouri and N. Miled. 2010. Effect of dietary vitamin $\mathrm{E}$ supplementation on lipid and colour stability of chicken thigh meat. African J. Biotech. 9(15):2276-2283 